\title{
Ismertetés: Mennyire hatékonyak a családalapú és az intézményi táplálkozási beavatkozások a gyermekek étrendjének és egészségének javításában? - Szisztematikus áttekintés
}

\author{
How effective are family-based and institutional nutrition interventions \\ in improving children's diet and health? - A systematic review
}

Ismerteti: Nagy Barbara $₫$

Országos Gyógyszerészeti és Élelmezés-egészségügyi Intézet

Szerzők: Andrew P. Black, Katina D'Onise, Robyn McDermott, Hassan Vally and Kerin O'Dea

Megjelenés: BMC Public Health, 2017, doi: https://doi.org/10.1186/s12889-017-4795-5

Beküldve: 2017. 11. 02.

doi: 10.24365/ef.v58i4.202

Kulcsszavak: családalapú programok, iskolai táplálkozási programok, szisztematikus áttekintés

Keywords: family-based programs, school nutrition programs, systematic overview

\section{ÖSSZEFOGLALÁS}

A tanulmány célja a családalapú és az iskolai/óvodai táplálkozási programok hatásának felmérése volt a $\leq 12$ éves gyermekek egészségére, beleértve e hatások fenntarthatóságát és a társadalmi-gazdasági egyenlőtlenségek jelentőségét. A szakirodalmi feldolgozás az 1980 és 2014 decembere között a témában megjelent publikációk szisztematikus áttekintésével történt. 39 tanulmány eredményéről számoltak be a szerzők, melyek mindegyike magas jövedelmű országokban élő, 12 éves kor alatti gyermekes családokat érintő randomizált kontrollált vizsgálat volt, ahol a fő kimeneti változót a táplálékbevitel és az egészségi állapot jelentette.
Tizennégy program a családok bevonására is tett lépéseket. $A$ beavatkozások többségét iskolákban $(n=25)$ vagy óvodákban $(n=6)$ végezték, egy általános, az egészséges táplálkozást elősegítő, több összetevőt tartalmazó megközelítéssel. Négy tanulmány iskolai étkeztetési, egy iskolakert, egy iskola gyümölcs, kettő iskolai étkezőket célzó programot mutatott be. Az eredmények alapján megfogalmazható, hogy a családalapú programok, amelyek egyszerű táplálkozási információkkal látják el a szülőket, nagymértékben csökkentik a zsírbevitelt és növelik a zöldség-, gyümölcsfogyasztást, míg az iskolarendszerú programok mérsékelten növelik a zöldség-és gyümölcsbevitelt.

\section{TANULSÁGOK A HAZAI SZAKEMBEREK SZÁMÁRA}

A családalapú és az iskolai táplálkozási programok javíthatják a táplálkozási szokásokat, azonban a pozitív hatások hosszú távú fenntarthatósága korlátozott. A hatékony programok tartalmaznak szerepmodelleket (kortárs, tanár), jutalmazást és az egészséges élelmiszerekhez való hozzáférést. 